DOI: https://doi.org/10.24127/ajpm.v10i2.3578

\title{
PENGEMBANGAN E-BOOK BERMUATAN HIGH ORDER THINKING SKILL (HOTS)
}

\author{
Anindita Ekaning Saputri ${ }^{1}$, Windia Hadi ${ }^{2 *}$ \\ 1,2* Universitas Muhammadiyah Prof. DR. HAMKA, Jakarta, Indonesia \\ ${ }^{*}$ Corresponding author. Cipondoh Makmur, Blok. G2/26, 15148, Banten, Indonesia. \\ E-mail: $\quad$ windia.hadi@uhamka.ac.id ${ }^{2 *}$
}

Received 20 February 2021; Received in revised form 28 June 2021; Accepted 01 July 2021

\begin{abstract}
Abstrak
Penelitian ini bertujuan untuk mengembangkan bahan ajar matematika bermuatan High Order Thinking Skill (HOTS) berupa buku ajar elektronik pada materi Statistika untuk siswa SMP kelas VIII yang layak. Metode penelitian yang digunakan dalam penelitian ini adalah metode penelitian pengembangan dengan menggunakan model ADDIE (Analysis, Design, Development, Implementation, and Evaluating). Subjek dalam penelitian ini adalah siswa SMP kelas VIII dan guru matematika di SMPN 2 Gunung Putri Bogor. Instrumen pengumpulan data yang digunakan adalah lembar validasi dan respon berupa angket, lalu teknik analisis datanya menggunakan skala likert. Hasil dari penelitian ini menunjukkan bahwa buku ajar yang dihasilkan memenuhi standar kelayakan, hal ini dilihat dari hasil validasi ahli materi yang memperoleh persentase $78 \%$ dengan kriteria baik dan hasil validasi ahli media juga ahli bahasa yang memperoleh persentase $88 \%$ dengan kriteria sangat baik. Selain itu, standar kelayakan dari buku ajar ini diperkuat dari hasil ujicoba produk kepada guru dan siswa yang memberikan respon positif terhadap bahan ajar ini. Dengan demikian, buku ajar elektronik matematika bermuatan HOTS ini dapat dikatakan layak dan dapat digunakan dalam pembelajaran.
\end{abstract}

Kata kunci: Bahan ajar; EBOOK; HOTS; penelitian dan pengembangan.

\begin{abstract}
This study aims to develop mathematics teaching materials containing High Order Thinking Skill (HOTS) in the form of electronic textbooks on Statistics material for decent VIII grade junior high school students. The research method used in this study is a development research method using the ADDIE model (Analysis, Design, Development, Implementation, and Evaluating). The subjects in this study were grade VIII junior high school students and mathematics teachers at SMPN 2 Gunung Putri Bogor. The data collection instrument used was a validation sheet and the response was in the form of a questionnaire, then the data analysis technique used a Likert scale. The results of this study indicate that the textbooks produced meet the eligibility standards, this can be seen from the validation results of material experts who obtained a percentage of $78 \%$ with good criteria and the validation results of media experts also linguists who obtained a percentage of $88 \%$ with very good criteria. In addition, the feasibility standard of this textbook was strengthened from the results of product trials to teachers and students who gave positive responses to these teaching materials. Thus, this HOTS-loaded mathematics electronic textbook can be said to be feasible and can used in learning.
\end{abstract}

Keywords: EBOOK; HOTS; research and development; teaching material.

This is an open access article under the Creative Commons Attribution 4.0 International License

\section{PENDAHULUAN}

Hasil survey Programme for International Student Assessment (PISA) pada tahun 2018 menunjukkan bahwa Indonesia berada pada peringkat
5 terbawah, dimana siswa Indonesia hanya sanggup sampai pada skor 396 dari skor 486 yang sudah ditentukan (OECD, 2020). Selain itu, dalam studi Trends in Internasional Mathematics 
and Science Study (TIMSS), Indonesia tertinggal dari negara-negara tetangganya seperti Malaysia dan Singapura, ini disebabkan karena skor rata-rata siswa Indonesia yang rendah dalam TIMSS (Mullis, Martin, Foy, \& Hooper, 2015).

$$
\text { Rendahnya prestasi siswa }
$$

Indonesia dalam PISA dan TIMSS dikarenakan belum semua tujuan pembelajaran matematika menerapkan penekanan pada pola pikir matematis yang merupakan cabang dari High Order Thinking Skill (HOTS). HOTS atau keterampilan berpikir tingkat tinggi adalah keterampilan berpikir kritis yang dimiliki seseorang, termasuk pada keterampilan berpikir matematis, seperti: menganalisis, mengevaluasi, dan menerapkan konsep matematika dalam penyelesaian masalah yang tepat, dimana proses berpikir tingkat tinggi itu akan terjadi ketika seseorang mendapatkan informasi baru yang saling berkaitan dengan informasi sebelumnya (Dinni, 2018). Tentunya HOTS ini sangat penting untuk guru juga siswa serta tidak bisa tercapai begitu saja dan perlu adanya upaya baik dari segi sarana juga media dalam pembelajaran yang memadai dan mendukung pembelajaran itu sendiri (Dinni, 2018; Hadi \& Faradillah, 2020). Salah satu sarana yang mampu untuk menuntaskan berbagai permasalahan yang ada adalah dengan adanya bahan ajar karena adanya bahan ajar menjadi sangat penting dalam proses pembelajaran, jika bahan ajar tidak ada maka guru dan siswa pun akan mengalami kesulitan (Perwitasari \& Akbar, 2018; Yuherni, Maimunah, \& Yuanita, 2020).

Berdasarkan wawancara dengan salah satu guru matematika di SMPN 2 Gunung Putri Bogor didapatkan informasi bahwasannya sangat minim sekali adanya buku ajar yang didalamnya memuat soal-soal HOTS, rata-rata guru hanya menggunakan bahan ajar yang sudah disediakan, sehingga pembelajaran hanya bertolak ukur pada satu buku ajar saja, dan buku ajar yang dipakai pun berbentuk cetak, sehingga sangat menyulitkan bagi siswa ditengah kondisi pandemi seperti ini. Padahal prestasi siswa sangat dipengaruhi dari buku teks dan pembelajaran akan lebih bermakna jika buku teks yang dipilih tepat (Perwitasari \& Akbar, 2018).

Sementara itu, terdapat beberapa studi literatur yang mengkaji mengenai pengembangan bahan ajar bermuatan HOTS diantaranya adalah yang dilakukan oleh Anisah \& Lastuti (2018) yang berhasil mengembangkan bahan ajar berbasis HOTS berupa modul untuk meningkatkan kemampuan pemecahan masalah matematis mahasiswa, keberhasilannya dapat dilihat dari kemampuan pemecahan masalah matematis yang menjadi sampel dalam penelitian ini, sebelumnya rata-rata yang dicapai adalah 57,50 dan setelah diberikan bahan ajar berbasis HOTS rata-ratanya meningkat menjadi 87,90 . Serupa dengan penelitian sebelumnya, Musfiqi \& Jailani (2014) juga berhasil mengembangkan bahan ajar berupa RPP dan LKS yang berorientasi pada HOTS dan karakter, dimana hasil dari angket yang sudah diberikan menunjukan peningkatan karakter siswa yang mencapai $100 \%$ dari sebelumnya $78 \%$ dan untuk soal-soal HOTS yang didapat dari hasil tes menunjukan peningkatan $74 \%$. Selain itu, ditemukan pula studi literatur lain yang berhasil mengembangkan bahan ajar berdasarkan HOTS berupa buku ajar matematika untuk kelas X SMA yang sudah teruji kelayakannya dari sudut pandang ahli materi, ahli media, ahli bahasa dan guru matematika menurut Hendriana, Kurniawan, \& Nuriadin (2019). Dari 
studi-studi literatur yang ditemukan, belum ditemukan penelitian pengembangan dengan memanfaatkan teknologi digital sebagai bahan ajar.

Berdasarkan masalah yang telah dijelaskan, oleh karenanya perlu dilakukan penelitian lanjutan karena saat ini sudah memasuki revolusi industri 4.0, dimana teknologi sudah mendominasi kehidupan setiap individunya dan pembelajaran sudah sepatutnya berbasis digital, terlebih ditengah pandemi virus corona yang mengharuskan guru dan siswa memiliki kemampuan lebih di bidang teknologi, bahkan berdasarkan fakta dilapangan hampir semua siswa memiliki Smartphone Android. Sehingga berangkat dari permasalahan yang telah dipaparkan, maka perlu adanya bahan ajar yang memanfaatkan teknologi seperti Electronic Book (Ebook). E-book sendiri memiliki arti sebuah buku dalam bentuk digital, dimana e-book mampu menampilkan informasi multimedia yang dikemas dalam bentuk tayangan suara, grafik, gambar, ataupun animasi, sehingga $e$ book memiliki banyak keunggulan jika disandingkan dengan buku konvensional (Triyono, Wardani, Hariyanto, \& Subhan, 2012). Selain itu, e-book dinilai sangat perlu karena pembelajaran butuh suatu inovasi yang interaktif dan mampu membuat pembelajaran lebih bervariasi, dimana dengan adanya inovasi maka pembelajaran akan lebih menarik, sehingga motivasi belajar siswa akan meningkat (Jalinus, Nabawi, \& Mardin, 2017; Masykur, Nofrizal, \& Syazali, 2017; Sagala, Umam, Thahir, Saregar, \& Wardani, 2019; Yulianti, Buchori, \& Murtianto, 2017).

Untuk itu bahan ajar juga perlu berkembang sebagaimana zaman sehingga mudah untuk diakses, menarik, dan praktis dalam pembelaja- ran. Disamping itu juga karena bahan ajar yang memanfaatkan teknologi seperti E-book yang mengimplementasikan HOTS bisa dikatakan masih jarang ditemukan. Sehingga ide tersebut tertuang dalam penelitian ini yang bertujuan untuk menghasilkan bahan ajar matematika bermuatan HOTS berupa E-book pada Materi Statistika untuk siswa SMP kelas VIII yang layak.

\section{METODE PENELITIAN}

Metode yang digunakan dalam penelitian ini adalah metode penelitian pengembangan (Research and Development), dimana produk yang dihasilkan dalam penelitian ini adalah bahan ajar matematika bermuatan High Order Thinking Skill (HOTS) berupa $E$ book pada materi Statistika untuk siswa SMP kelas VIII. Subjek dalam penelitian ini adalah siswa kelas VIII SMPN 2 Gunung Putri Bogor yang terdiri dari 3 siswa untuk tahap pertama dan 34 siswa untuk tahap kedua, selain itu penelitian ini juga melibatkan 3 orang guru matematika SMPN 2 Gunung Putri Bogor. Penelitian ini menggunakan model ADDIE (Analysis, Design, Development, Implementation, and Evaluating), dimana model ini dinilai selaras juga tepat dengan karakteristik pengembangan bahan ajar dan juga bahan manipulasi lainnya dalam pembelajaran. Menurut (Muruganantham, 2015) model ADDIE ini terdiri dari 5 tahapan yaitu Analysis, Design, Development, Implementation, and Evaluating.

Tahap analisis dilakukan sebelum penelitian, dimana analisis yang dimaksud adalah untuk mengetahui permasalahan apa saja yang dialami siswa dalam memecahkan suatu masalah matematika yang diorientasikan pada HOTS. Selain itu, ditahap inilah terjadi proses menganalisis 
keperluan bahan ajar yang akan dikembangkan dan melihat kebaruan dari produk yang akan dikembangkan.

Selanjutnya, pada tahap desain bahan ajar akan disusun dengan mengkaji lebih dulu KI dan KD. Hal ini bertujuan untuk menentukan materi, memetakan kebutuhan bahan ajar, menentukan struktur bahan ajarnya, dan menyusun instrumen penilaian yang nantinya akan divalidasi oleh validator serta menyusun instrumen angket respon yang nantinya akan diisi oleh guru juga siswa.

Tahap selanjutnya ialah pengembangan. Pada tahap inilah akan disusun bahan ajar dari apa yang sudah dibuat dan direncanakan di tahap sebelumnya. Dalam tahap ini juga akan dihasilkan sebuah bahan ajar yang kemudian akan di validasi oleh para ahli untuk melihat apakah bahan ajar sudah layak atau belum. Jika sudah dikatakan layak maka bahan ajar akan masuk di tahap selanjutnya. Akan tetapi, jika belum dikatakan layak maka bahan ajar akan direvisi dan divalidasi kembali sampai bahan ajar dikatakan layak.

Setelah diperoleh bahan ajar yang layak, tahapan selanjutnya adalah tahap implementasi. Pada tahap inilah bahan ajar yang sudah dikembangkan dan sudah dikatakan layak ditahap sebelumnya akan diuji coba pada kelompok kecil dan kelompok besar yang melibatkan siswa SMP kelas VIII. Selain itu, bahan ajar ini juga akan di uji coba kepada guru matematika.

Tahapan akhir, yaitu tahap evaluasi. Pada tahap inilah akan dilakukan umpan balik terhadap bahan ajar yang sudah dikembangkan dan dalam tahap ini pula dilakukan tahap revisi terakhir. Bahan ajar yang dikembangkan akan dinilai secara keseluruhan, sehingga dapat dilihat apakah layak atau tidak.
Penelitian ini menggunakan instrumen pengumpulan data berupa angket, dimana angket ini ditunjukan kepada validator dan subjek penelitian dalam bentuk google form yang dipakai untuk melihat sejauh mana kelayakan dari produk yang dikembangkan, dimana instrumennya meliputi 1) lembar validasi ahli materi, 2) lembar validasi ahli bahasa, 3) lembar validasi ahli media, 4) lembar respon guru dan 5) lembar respon siswa. Tingkat kelayakannya dinilai dari sudut pandang para ahli yang merupakan Bapak/Ibu dosen sesuai bidangnya yang terdiri dari 3 orang untuk ahli materi, 1 orang untuk ahli media dan 1 orang untuk ahli bahasa. Teknik analisis data dalam penelitian ini terdiri dari data kualitatif dan kuantitatif, dimana data kualitatifnya meliputi saran para ahli terhadap bahan ajar dan data kuantitatifnya adalah perhitungan ataupun analisis data yang digunakan.

Data dari angket yang sudah terkumpul akan dianalisis dengan menggunakan skala likert. Skala ini digunakan untuk menilai sikap, pendapat, dan persepsi masyarakat atau individu (Sugiyono, 2015). Skala likert yang digunakan dalam penelitian ini terdiri dari 5 pilihan pada setiap butir pernyataan atau pertanyaannya, dimana skor 1 adalah skor terendah dan skor 5 adalah skor tertinggi. Setelah diperoleh hasil secara kuantitatif, hasil tersebut kemudian diinterpretasikan ke dalam bentuk kualitatif. Adapun kriteria interpretasi skor validasi para ahli disajikan dalam Tabel 1. Selanjutnya juga disajikan kriteria interpretasi skor respon guru dan siswa berdasarkan interval untuk melihat tingkat interpretasi dari hasil persentase indeks. Kriteria interpretasi ini tertera pada Tabel 2. 
DOI: https://doi.org/10.24127/ajpm.v10i2.3578

Tabel 1. Kriteria interpretasi skor validasi para ahli

\begin{tabular}{ccccc}
\hline \multicolumn{3}{c}{ Interval Persentase } & \multirow{2}{*}{ Skor } & \multirow{2}{*}{ Kriteria } \\
\cline { 1 - 3 } Validasi Materi & Validasi Media & Validasi Bahasa & & \\
\cline { 1 - 3 } $0 \%<x \leq 36 \%$ & $0 \%<x \leq 36 \%$ & $0 \%<x \leq 37 \%$ & 1 & Sangat Kurang \\
$36 \%<x \leq 53 \%$ & $36 \%<x \leq 52 \%$ & $37 \%<x \leq 53 \%$ & 2 & Kurang \\
$53 \%<x \leq 69 \%$ & $52 \%<x \leq 68 \%$ & $53 \%<x \leq 70 \%$ & 3 & Cukup \\
$69 \%<x \leq 85 \%$ & $68 \%<x \leq 85 \%$ & $70 \%<x \leq 87 \%$ & 4 & Baik \\
$85 \%<x \leq 100 \%$ & $85 \%<x \leq 100 \%$ & $87 \%<x \leq 100 \%$ & 5 & Sangat Baik \\
\hline
\end{tabular}

Tabel 2. Kriteria interpretasi skor respon guru dan siswa

\begin{tabular}{cccc}
\hline \multicolumn{2}{c}{ Interval Persentase } & \multirow{2}{*}{ Skor } & \multirow{2}{*}{ Kriteria } \\
\hline Respon Guru Matematika & Respon Siswa & & \\
\hline $0 \%<x \leq 36 \%$ & $0 \%<x \leq 36 \%$ & 1 & Tidak Setuju \\
$36 \%<x \leq 51 \%$ & $36 \%<x \leq 53 \%$ & 2 & Kurang Setuju \\
$51 \%<x \leq 67 \%$ & $53 \%<x \leq 69 \%$ & 3 & Ragu-ragu \\
$67 \%<x \leq 83 \%$ & $69 \%<x \leq 85 \%$ & 4 & Setuju \\
$83 \%<x \leq 100 \%$ & $85 \%<x \leq 100 \%$ & 5 & Sangat Setuju \\
\hline
\end{tabular}

Sesuai dengan kriteria interprestasi skor untuk para ahli, bahan ajar yang sudah dikembangkan akan terlihat memenuhi standar kelayakan jika tingkat kelayakannya mencapai interprestasi baik atau sangat baik. Sementara untuk angket respon guru dan siswa, bahan ajar yang sudah dikembangkan akan terlihat memenuhi standar kelayakan jika tingkat kelayakannya mencapai interprestasi setuju atau sangat setuju, dimana hal itu berarti respon yang diberikan oleh guru dan siswa adalah respon positif.

\section{HASIL DAN PEMBAHASAN}

Sesuai dengan model yang diadopsi dalam penelitian ini yakni model ADDIE maka penelitian pengembangan ini melalui 5 tahapan yakni analysis, design, development, implementation, and evaluating. Berikut adalah penjelasan dan data dari hasil setiap tahapan yang dilakukan dalam penelitian ini.

\section{Tahap Analisis}

Berdasarkan penelitian relevan, sangat minim sekali penelitian yang mengangkat topik tentang pengembangan suatu bahan ajar yang bermuatan High Order Thinking (HOTS), terlebih jika bahan ajar itu dikemas dalam bentuk digital, sebab saat ini teknologi sudah menjadi kebutuhan, dimana semua orang mudah mengaksesnya, terlebih di masa pandemi ini. Selain itu, dilihat dari pembelajaran dikelas khususnya pada pembelajaran matematika, siswa ketika diberikan soal-soal yang bermuatan HOTS akan merasa kesulitan karena dalam pembelajarannya belum terbiasa sebab kesehariannya siswa hanya diberikan soal-soal rutin saja dan buku ajar yang digunakan pun sangat minim memuat soal-soal HOTS. Oleh karenanya, setiap siswa perlu membiasakan diri berhadapan dengan soal HOTS agar terbiasa dan tidak lagi memiliki mindset sulit ketika dihadapkan dengan soal-soal HOTS. Berdasarkan hal tersebut, maka sangat perlu adanya buku ajar elektronik ini 
untuk memudahkan dan membantu siswa dalam belajar dan meningkatkan HOTS.

\section{Tahap Desain}

Hasil pada tahap analisis akan dijadikan pedoman dalam pembuatan desain. Proses yang dilakukan di tahap desain diantaranya adalah: (a) penetapan tujuan yang disesuaikan dari hasil analisis, (b) penyajian materi, (c) penulisan naskah sebagai gambaran terkait apa saja yang akan disajikan, (d) gambaran tampilan secara garis besar berupa desain template, dan (e) perancangan alat evaluasi untuk melihat kelayakan bahan ajar.

\section{Tahap Pengembangan}

Dalam tahap pengembangan, sudah mulai disusun bahan ajar yang dikembangkan, mulai dari penempatan desain dan ilustrasi hingga isi materi. Materi yang dipilih dalam pengembangan bahan ajar matematika bermuatan HOTS berupa buku elektronik ini adalah materi statistika untuk siswa SMP kelas VIII. Dalam penulisan buku ajar ini, peneliti berpedoman pada komponen penilaian yang ada dalam BSNP (Badan Standar Nasional Pendidikan) seperti kelayakan isi, kelayakan penyajian, kelayakan bahasa juga kelayakan kegrafikkan. Sementara untuk penulisan soal-soal yang ada dalam buku ajar, peneliti berpedoman pada indikator di dalam HOTS yang didasarkan pada level kognisi taksonomi bloom yakni menganalisis, mencipta dan mengevaluasi. Untuk desain, ilustrasi dibuat dengan menggunakan aplikasi Medibang Paint, sementara untuk penempatan dan penyatuan warna serta isi menggunakan Adobe Photoshop dan Microsoft Office Word 2010.

Pada tahap pengembangan inilah, buku ajar yang dikembangkan selesai.
Tampilan awal buku ajar dapat dilihat pada Gambar 1.

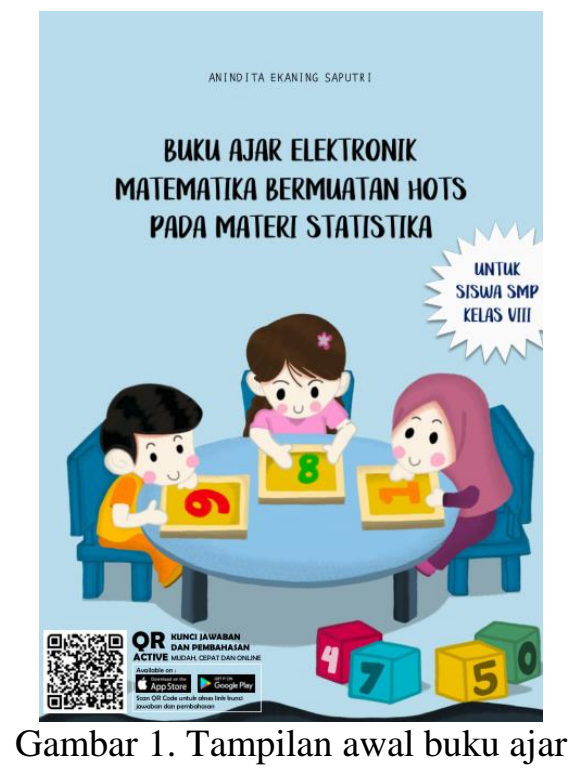

Selanjutnya setelah tampilan awal, tampilan peta konsep dapat dilihat pada Gambar 2.

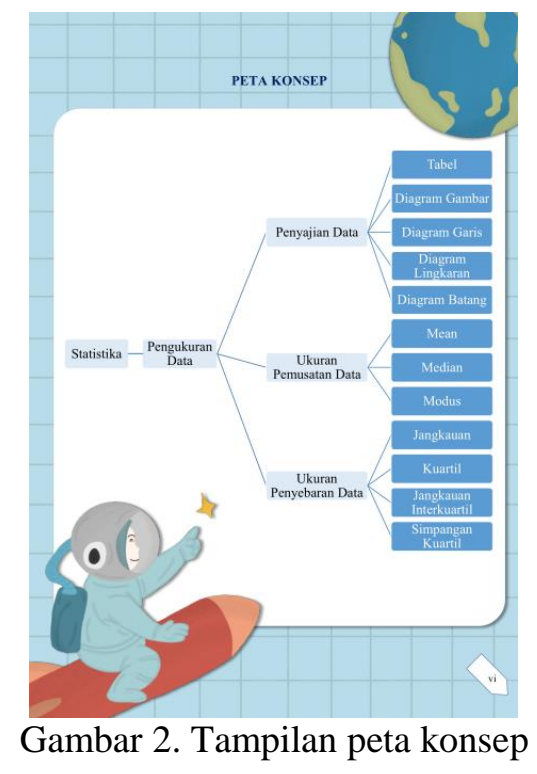

Selain itu, berikut adalah tampilan isi materi statistika bermuatan HOTS yang dapat dilihat pada Gambar 3. 
DOI: https://doi.org/10.24127/ajpm.v10i2.3578

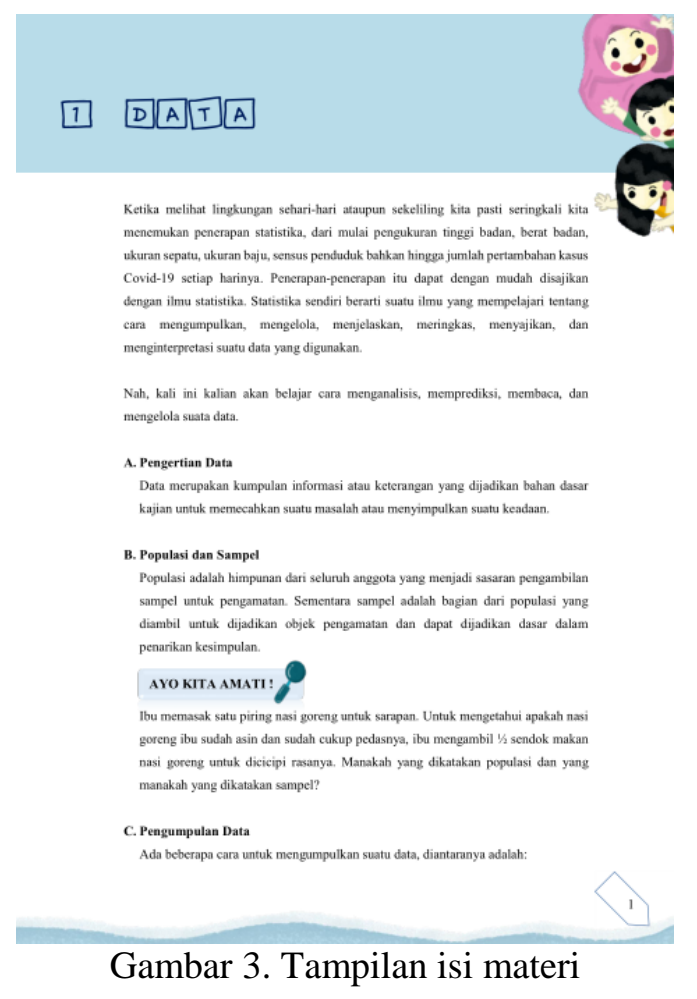

Pada buku ajar elektronik ini, juga terdapat contoh soal yang dikemas dengan ilustrasi menarik dan dikaitkan dengan keseharian siswa seperti tampak pada Gambar 4.

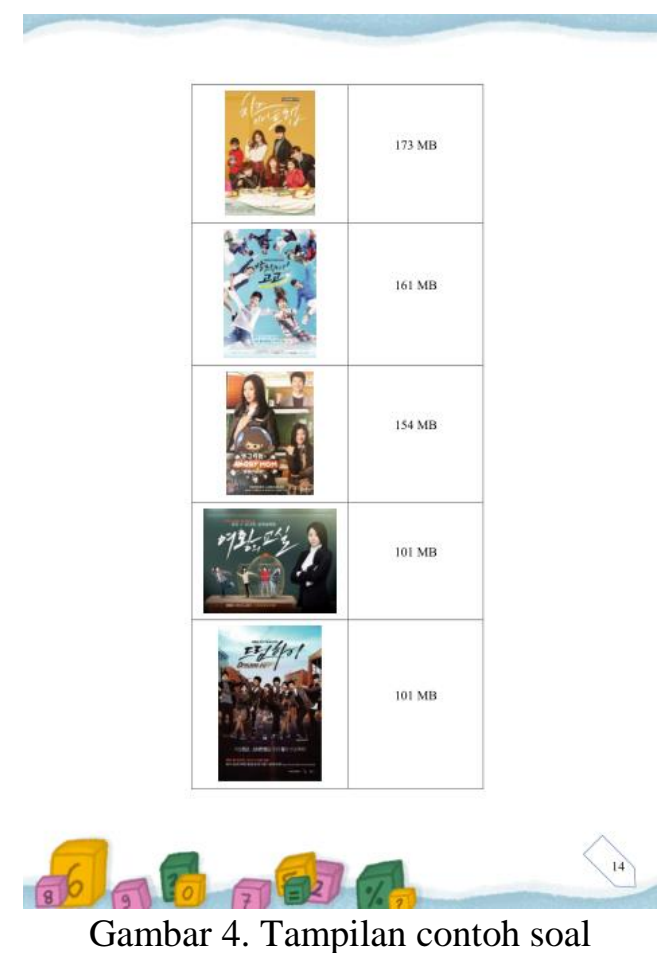

1014
Disamping itu juga, terdapat latihan soal bermuatan HOTS yang dapat dilihat pada Gambar 5.
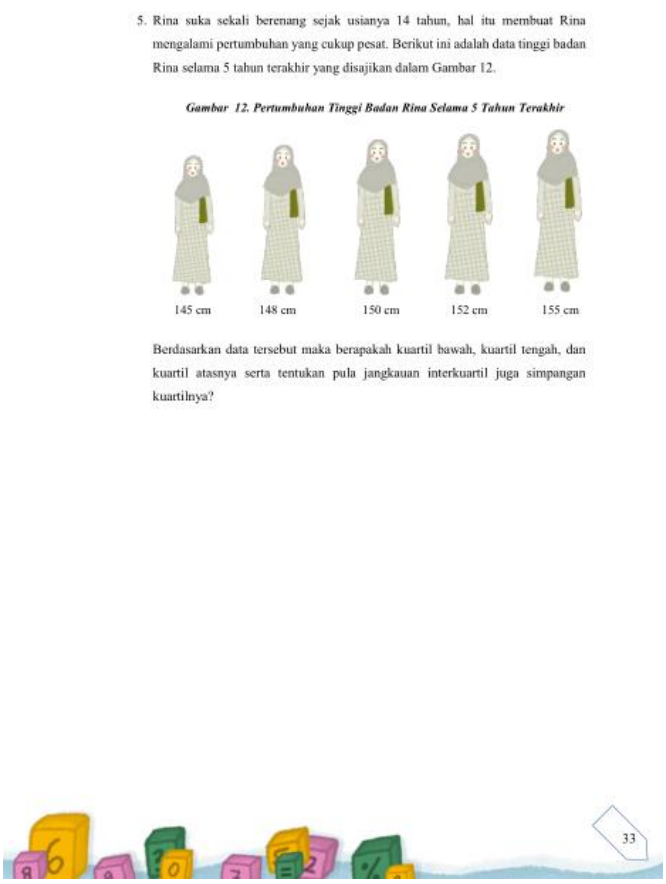

Gambar 5. Tampilan latihan soal

Selanjutnya, buku ajar akan di validasi oleh para ahli yang merupakan Bapak/Ibu dosen sesuai bidangnya. Validasi dilakukan untuk mengetahui tingkat kelayakan dari buku ajar. Sehingga, setelah proses validasi selesai akan terlihat apakah buku ajar sudah layak atau belum. Selain itu, dalam validasi juga terdapat kolom komentar dan saran perbaikan agar buku ajar benar-benar layak ketika akan diuji cobakan.

\section{Hasil Validasi Ahli Materi}

Validasi materi bertujuan untuk mengetahui tingkat kesesuaian, keakuratan, kelengkapan, dan keruntutan materi juga teknik penyajian. Ahli materi yang memvalidasi terdiri dari 3 dosen Matematika dari Universitas Muhammadiyah Prof. Dr. Hamka. Hasil validasi disajikan dalam Tabel 3 dan 4. 
DOI: https://doi.org/10.24127/ajpm.v10i2.3578

Tabel 3. Hasil validasi ahli materi dalam aspek kelayakan materi

\begin{tabular}{|c|c|c|c|}
\hline Indikator & Ahli & $\%$ & Kategori \\
\hline \multirow{4}{*}{$\begin{array}{l}\text { Kesesuaian } \\
\text { Materi dengan } \\
\text { SK dan KD }\end{array}$} & A & $73 \%$ & Baik \\
\hline & & & Sangat \\
\hline & B & $100 \%$ & Baik \\
\hline & $\mathrm{C}$ & $73 \%$ & Baik \\
\hline \multirow{3}{*}{$\begin{array}{l}\text { Keakuratan } \\
\text { Materi }\end{array}$} & A & $77 \%$ & Baik \\
\hline & B & $87 \%$ & $\begin{array}{l}\text { Sangat } \\
\text { Baik }\end{array}$ \\
\hline & $\mathrm{C}$ & $80 \%$ & Baik \\
\hline Kemuktahiran & A & $80 \%$ & Baik \\
\hline \multirow[t]{2}{*}{ Materi } & B & $80 \%$ & Baik \\
\hline & $\mathrm{C}$ & $80 \%$ & Baik \\
\hline Mendorong & A & $80 \%$ & Baik \\
\hline \multirow[t]{2}{*}{ Keingintahuan } & B & $80 \%$ & Baik \\
\hline & $\mathrm{C}$ & $60 \%$ & Cukup \\
\hline \multicolumn{2}{|c|}{ Total Indikator } & $80 \%$ & Baik \\
\hline
\end{tabular}

Tabel 4. Hasil validasi ahli materi dalam aspek kelayakan penyajian

\begin{tabular}{lccc}
\hline Indikator & Ahli & \% & Kategori \\
\hline Teknik & A & $80 \%$ & Baik \\
Penyajian & B & $60 \%$ & Cukup \\
& C & $80 \%$ & Baik \\
Pendukung & A & $73 \%$ & Baik \\
Penyajian & B & $77 \%$ & Baik \\
& C & $67 \%$ & Cukup \\
Penyajian & A & $90 \%$ & Sangat Baik \\
Pembelajaran & B & $90 \%$ & Sangat Baik \\
& C & $70 \%$ & Baik \\
Koherensi & A & $80 \%$ & Baik \\
\&Keruntutan & B & $80 \%$ & Baik \\
Alur Pikir & C & $70 \%$ & Baik \\
\hline \multicolumn{2}{c}{ Total Indikator } & $\mathbf{7 5 \%}$ & Baik \\
\hline
\end{tabular}

Sesuai dengan hasil validasi oleh ahli materi, diperoleh rata-rata keseluruhan sebesar $78 \%$ dengan kriteria "BAIK", dimana dari isi materi, penyajian materi dan kesesuaian materi dengan indikator HOTS sudah bisa dikatakan sesuai dan tepat. Saran yang diberikan untuk buku ajar elektronik ini adalah desain dibuat lebih menarik lagi pada bagian isi, jumlah soal dan referensi diperbanyak, penggunaan kata depan harus dipisah, tanda seru atau tanda tanya cukup satu kali saja namun diperhatikan betul penempatannya, dan untuk tabel serta gambar harus diberi keterangan nama. Berdasarkan data hasil validasi dan saran perbaikan dari ahli media, bisa disimpulkan bahwa buku ajar elektronik matematika bermuatan HOTS ini sudah valid sebab mencapai kriteria "baik" secara keseluruhan dan sudah dapat diuji cobakan dengan revisi sesuai saran perbaikan dari ahli materi.

\section{Hasil Validasi Ahli Media}

Validasi ini bertujuan untuk mengetahui sejauh mana kelayakan dalam aspek kegrafikkannya, terkat pemilihan font, ilustrasi, warna, dan lainnya. Ahli media yang memvalidasi terdiri dari 1 orang dosen matematika dari Universitas Pamulang. Berikut adalah data hasil validasi ahli media yang disajikan dalam Tabel 5 .

Tabel 5. Hasil validasi ahli media

\begin{tabular}{lcc}
\hline Indikator & $\mathbf{\%}$ & Kategori \\
\hline Ukuran & $90 \%$ & Sangat Baik \\
Desain Sampul & $83 \%$ & Baik \\
Desain Isi & $89 \%$ & Sangat Baik \\
\hline Total Indikator & $\mathbf{8 8 \%}$ & Sangat Baik \\
\hline
\end{tabular}

Sesaui dengan hasil validasi oleh ahli media, diperoleh rata-rata keseluruhan kelayakan kegrafikkan sebesar $88 \%$ dengan kriteria "SANGAT BAIK", dimana tampilan awal dan tampilan isi materi serta tampilan keseluruhan sudah bagus, selain itu untuk font dan tata letak penyajiannya pun rapih juga mudah dibaca dan tidak mengganggu isi materi.

Saran yang diberikan untuk buku ajar elektronik ini adalah desain sampul dan keseluruhan sudah cukup baik hanya saja saat masuk dibagian materi terlalu polos, mungkin bisa diberikan aksen gambar atau ilustrasi yang tidak mengganggu atau permainan warna 
yang selaras dan untuk pilihan ganda berupa angka lebih baik dibuat konsisten dan urut dari kecil ke besar atau sebaliknya serta untuk kegiatan menalar, menganalisis dan lainnya dibuat konsisten dalam setiap sub materi. Berdasarkan data hasil validasi dan saran perbaikan dari ahli media, bisa disimpulkan bahwa buku ajar elektronik matematika bermuatan HOTS ini sudah valid dan sudah dapat diuji cobakan dengan revisi sesuai saran perbaikan dari ahli media.

\section{Hasil Validasi Ahli Bahasa}

Validasi ini bertujuan untuk mengetahui apakah bahasa yang digunakan dalam buku ajar yang telah dibuat ini sudah sesuai atau belum, komunikatif atau belum, lugas dan interaktif atau belum dan aspek lainnya. Ahli bahasa yang memvalidasi bahasa dari bahan ajar yang telah dikembangkan ini terdiri dari 1 orang dosen Pendidikan Bahasa Indonesia dari Universitas Muhammadiyah Prof. Dr. Hamka. Berikut adalah data hasil validasi ahli bahasa yang disajikan dalam Tabel 6 .

Tabel 6. Hasil validasi ahli bahasa

\begin{tabular}{lcc}
\hline Indikator & \% & Kategori \\
\hline Ukuran & $90 \%$ & Sangat Baik \\
Desain Sampul & $83 \%$ & Baik \\
Desain Isi & $89 \%$ & Sangat Baik \\
\hline Total Indikator & $\mathbf{8 8 \%}$ & Sangat Baik \\
\hline
\end{tabular}

Dari hasil validasi oleh ahli bahasa, diperoleh rata-rata keseluruhan kelayakan bahasa sebesar 88\% dengan kriteria "SANGAT BAIK", dimana bahasa yang dipakai sudah sesuai dengan EYD dan kalimat atau istilah yang dipakai sudah efektif serta sesuai dengan KBBI. Sehingga, bisa disimpulkan bahwa bahan ajar matematika bermuatan HOTS berupa buku elektronik ini sudah valid dan dapat diujicobakan dengan revisi sesuai saran dan kritik dari ahli bahasa.

\section{Tahap Implementasi}

Setelah bahan ajar yang dikembangkan dikatakan valid atau layak maka selanjutnya adalah tahap implementasi yaitu dengan melakukan uji coba. Uji coba yang pertama dilakukan kepada kelompok kecil yang merupakan siswa SMP kelas VIII di SMPN 2 Gunung Putri berjumlah 3 siswa dengan kriteria prestasi matematika tinggi, rendah dan sedang. Uji coba ini dilakukan untuk melihat respon ataupun tanggapan siswa terkait bahan ajar yang telah dikembangkan. Berikut ini adalah hasil respon dari ketiga siswa terkait bahan ajar yang telah dikembangkan yang tersaji dalam Tabel 7.

Tabel 7. Hasil respon siswa dalam kelompok kecil

\begin{tabular}{lccc}
\hline Indikator & Siswa & $\%$ & Kategori \\
\hline Ketertari- & $\mathrm{A}$ & $89 \%$ & Sangat Setuju \\
kan & $\mathrm{B}$ & $71 \%$ & Setuju \\
& $\mathrm{C}$ & $74 \%$ & Setuju \\
Materi & $\mathrm{A}$ & $83 \%$ & Setuju \\
& $\mathrm{B}$ & $100 \%$ & Sangat Setuju \\
& $\mathrm{C}$ & $80 \%$ & Setuju \\
Bahasa & $\mathrm{A}$ & $73 \%$ & Setuju \\
& $\mathrm{B}$ & $100 \%$ & Sangat Setuju \\
& $\mathrm{C}$ & $87 \%$ & Sangat Setuju \\
\hline \multicolumn{2}{c}{ Total Aspek } & $\mathbf{8 3 \%}$ & Setuju \\
\hline
\end{tabular}

Hasil respon siswa dalam kelompok kecil terhadap bahan ajar yang dikembangkan ini memperoleh rata-rata persentase sebesar $83 \%$, dimana respon yang diberikan siswa adalah respon positif dengan kriteria "SETUJU" pada setiap indikator penilaiannya, seperti mereka menyukai tampilannya, mereka memahmi setiap konsep yang disajikan dan mereka 
menyukai setiap contoh yang selalu dikaitkan dengan sesuatu yang tidak asing dengan mereka. Hal ini berarti buku ajar elektronik matematika bermuatan HOTS pada materi statistika untuk siswa SMP kelas VIII yang dikembangkan disukai dan sesuai dengan siswa sehingga layak untuk dijadikan salah satu rujukan dalam kegiatan belajar mengajar dikelas.

Selanjutnya bahan ajar akan diuji coba dalam kelompok besar setelah melalui proses perbaikan. Uji coba kelompok besar ini dilakukan untuk memperkuat, meyakinkan dan mengetahui apakah benar produk yang dikembangkan ini sudah layak atau belum. Uji coba pada kelompok besar ini melibatkan 34 siswa SMP kelas VIII dalam 1 kelas di SMPN 2 Gunung Putri. Berikut ini adalah rata-rata hasil respon dari 34 siswa yang disajikan dalam Tabel 8.

Tabel 8. Hasil respon siswa dalam kelompok besar

\begin{tabular}{lcc}
\hline Indikator & \% & Kategori \\
\hline Ketertarikan & $82 \%$ & Setuju \\
Materi & $82 \%$ & Setuju \\
Bahasa & $87 \%$ & Sangat Setuju \\
\hline Total Aspek & $\mathbf{8 3 \%}$ & Setuju \\
\hline
\end{tabular}

Hasil respon siswa dalam kelompok besar terhadap bahan ajar yang dikembangkan ini memperoleh rata-rata persentase keseluruhan indikator penilaian sebesar $83 \%$, dimana respon yang diberikan siswa adalah respon positif dengan kriteria "SETUJU". "Setuju" yang dimaksud ini adalah siswa setuju bahwa tampilan dalam buku ajar sangat menarik dan materi yang disajikan mudah dipahami sebab banyak ilustrasi yang dikaitkan dengan kehidupan sehari-hari serta bahasa yang dipakai dalam buku ajar pun bahasa yang sangat mudah untuk dipahami. Hal ini berarti buku ajar elektronik matematika bermuatan HOTS pada materi statistika untuk siswa SMP kelas VIII yang dikembangkan disukai dan sesuai dengan siswa sehingga layak untuk dijadikan salah satu rujukan dalam kegiatan belajar mengajar dikelas.

Setelah dilakukan uji coba produk pada kelompok kecil dan kelompok besar yang melibatkan siswa, maka langkah selanjutnya adalah uji coba produk kepada pendidik, yakni guru matematika di SMPN 2 Gunung Putri berjumlah 3 orang, dimana hal ini bertujuan untuk lebih meyakinkan, menguatkan dan mengetahui apakah memang benar produk yang dikembangkan itu sudah layak di gunakan dalam sebuah pembelajaran atau belum. Berikut ini adalah hasil respon dari guru matematika di SMPN 2 Gunung Putri yang disajikan dalam Tabel 9.

Tabel 9. Hasil respon guru matematika

\begin{tabular}{lccc}
\hline Indikator & Guru & \% & Kategori \\
\hline Komponen & A & $80 \%$ & Sangat Setuju \\
isi dan & B & $80 \%$ & Setuju \\
penyajian & C & $80 \%$ & Setuju \\
Komponen & A & $80 \%$ & Setuju \\
Bahasa & B & $80 \%$ & Sangat Setuju \\
& C & $80 \%$ & Setuju \\
Komponen & A & $80 \%$ & Setuju \\
tampilan & B & $80 \%$ & Sangat Setuju \\
media & C & $77 \%$ & Sangat Setuju \\
\hline \multicolumn{2}{c}{ Total Aspek } & $\mathbf{8 0 \%}$ & Setuju \\
\hline
\end{tabular}

Hasil uji coba produk pada guru matematika di SMPN 2 Gunung Putri memperoleh rata-rata persentase sebesar $80 \%$, dimana rata-rata respon yang diberikan guru matematika adalah respon positif dengan kategori "Setuju", setuju yang dimaksud ini adalah guru matematika setuju bahwa isi dalam buku ajar sudah mencakup indikator HOTS dan sesuai KI juga KD, selain itu 
maksud setuju ini juga mengarah pada penjian buku ajar yang menarik dan desain yang bagus dan penggunaan bahasa yang tepat. Sehingga, dapat disimpulkan dari hasil uji coba produk pada siswa dengan kelompok kecil dan kelompok besar serta uji coba produk kepada guru matematika yang mana hasil uji cobanya menunjukan rata-rata "setuju" yang berarti bahwa buku ajar elektronik ini memang layak untuk dijadikan salah satu rujukan dalam kegiatan pembelajaran.

\section{Tahap Evaluasi}

Berdasarkan tahap implementasi, maka buku ajar elektronik matematika yang dihasilkan perlu dievaluasi. Pada tahap inilah revisi terakhir dari produk yang dikembangkan berdasarkan saran dan juga masukan dari guru dan siswa selama tahap implementasi. Hasil tanggapan dari guru, didapatkan saran agar judul dari buku yang dihasilkan dibuat lebih spesifik lagi, dan diharapkan pula bahwa kedepannya akan dihasilkan buku ajar elektronik kembali dengan materi matematika yang beragam agar mempermudah siswa untuk berlatih soal-soal HOTS, serta diharapkan agar gambar atau ilustrasi yang ada dalam buku ajar elektronik ini diperbanyak untuk memotivasi siswa dalam belajar matematika.

Sementara itu, rata-rata hasil pendapat dari siswa terhadap buku ajar elektronik ini adalah sangat membantu dalam memahami matematika terkhusus materi statistika, bukunya sangat menarik karena banyak gambar dan warna, bahasanya mudah dipahami, materinya pun lengkap dan banyak soalsoal latihan HOTS. Rata-rata saran yang diberikan siswa terhadap buku ajar elektronik ini adalah gaya penulisan buku diubah karena gaya penulisannya masih sama seperti buku pada umumnya sehingga minat membaca kurang, semoga buku elektronik ini segera ada dalam bentuk cetak, dan gambar serta permainan warnanya diperbanyak lagi.

Hasil dari penelitian ini menunjukan bahwa buku ajar terbukti mampu untuk menjembatani siswa dalam meningkatkan kemampuan berpikir tingkat tingginya, dimana hal ini sejalan dengan (Perwitasari \& Akbar, 2018) yang menyatakan bahwa buku teks adalah media ajar yang penting dalam sebuah pembelajaran. Selain itu, buku ajar elektronik ini dinilai efektif untuk dijadikan rujukan dalam sebuah pembelajaran matematika, hal ini sejalan dengan (Munandar \& Rizki, 2019) yang menyatakan bahwa buku ajar yang mengintegrasikan teknologi lebih praktis, tidak memakan tempat, mudah diakses dan juga tidak perlu mengeluakan banyak biaya.

Dalam proses penelitian, buku ajar elektronik matematika bermuatan HOTS yang diberikan kepada siswa memberikan banyak tanggapan positif. Siswa menjadi lebih tertarik dengan buku ajar elektronik karena dikemas dengan ilustrasi dan warna yang baik, dari hal tersebut siswa menjadi termotivasi dan semangat untuk membaca serta berlatih soal HOTS. Hal positif yang hadir tersebut berdampak langsung pada kemampuan berpikir tingkat tinggi yang dimiliki siswa.

Tentunya keberhasilan dalam penelitian ini didukung dari penelitianpenelitian yang relevan, diantaranya adalah penelitian yang dilakukan oleh (Munawaroh, Degeng, \& Sitompul, 2021) yang menghasilkan buku ajar matematika berbasis HOTS untuk siswa kelas VII SMP pada materi bilangan, dinilai layak untuk digunakan karena 
sudah memenuhi standar kelayakan. Selain itu, buku ajar tersebut dapat digunakan untuk melatih kemampuan berpikir tingkat tinggi siswa, khususnya pada materi bilangan. Dalam sudut pandang HOTS dan kaitannya, penelitian ini didukung dengan penelitian yang dilakukan oleh (Widodo \& Kadarwati, 2013) yang berhasil meningkatkan akivitas siswa, karakter siswa dan hasil belajar siswa dengan penerapan Higher Order Thinking berdasarkan Problem Based Instruction, dimana aspek-aspek seperti bernalar, menganalisis, dan mengevaluasi adalah aspek yang sangat diperhatikan, sehingga penerapan tersebut berfungsi dengan baik. Ada pula penelitian yang dilakukan oleh (Rosyi, Hartono, \& Fatirul, 2020) dimana penelitiannya berhasil menciptakan buku ajar matematika yang tidak hanya efektif untuk meningkatkan kemampuan berpikir tingkat tinggi, namun juga menarik dan memudahkan siswa memahami setiap soal, hal tersebut bisa diraih karena bersandar pada aspekaspek HOTS yang dikolaborasikan dengan bentuk visual dan gambar yang mencolok juga kontras. Hal ini berarti bahwa bahan ajar yang dikembangkan dengan memuat HOTS tidak hanya mampu untuk meningkatkan kemampuan berpikir tingkat tinggi saja, namun juga mampu untuk meningkatkan kemampuan pemecahan masalah matematis dan meningkatkan karakter dalam diri siswa.

\section{KESIMPULAN DAN SARAN}

Berdasarkan hasil penelitian pengembangan bahan ajar berupa buku ajar elektronik matematika bermuatan HOTS pada materi statistika untuk siswa SMP kelas VIII dan berdasarkan hasil analisis datanya maka dapat diambil kesimpulan bahwasannya buku ajar elektronik matematika ini adalah buku ajar yang layak, sehingga siap untuk digunakan dalam pembelajaran matematika khususnya pada materi statistika untuk siswa SMP kelas VIII. Saran untuk penelitian selanjutnya, perlu dikembangkan kembali bahan ajar berbasis digital yang mampu meningkatkan kemampuan berpikir tingkat tinggi siswa pada materi lain dan perlu adanya bahan ajar digital selain ebook yang dikembangkan seperti video atau lainnya, dimana hal ini tentu bertujuan agar bahan ajar yang dikembangkan mampu memfasilitasi siswa untuk memahami materi ajar.

\section{DAFTAR PUSTAKA}

Anisah, \& Lastuti, S. (2018). Pengembangan Bahan Ajar berbasis HOTS untuk Meningkatkan Kemampuan Pemecahan Masalah Matematis Mahasiswa. Kreano: Jurnal Matematika Kreatif-Inovatif, 9(2), 191-197.

https://doi.org/10.15294/kreano.v 9i2.16341

Dinni, H. N. (2018). HOTS ( High Order Thinking Skills ) dan Kaitannya dengan Kemampuan Literasi Matematika. Prisma, Prosiding Seminar Nasional Matematika, 1, 170-176.

Hadi, W., \& Faradillah, A. (2020). Hambatan Mahasiswa Calon Guru Matematika Dalam Menyelesaikan Masalah Bermuatan High-Order Thinking Skills. AKSIOMA: Jurnal Program Studi Pendidikan Matematika, 9(3), 662-670.

Hendriana, B., Kurniawan, R., \& Nuriadin, I. (2019). Pengembangan Buku Ajar Matematika Kelas X Sma Berbasis Hots. Kalamatika: 
DOI: https://doi.org/10.24127/ajpm.v10i2.3578

Jurnal Pendidikan Matematika, 4(2), 163-176. https://doi.org/10.22236/kalamati ka.vol4no2.2019pp163-176

Jalinus, N., Nabawi, R. A., \& Mardin, A. (2017). The Seven Steps of Project Based Learning Model to Enhance Productive Competences of Vocational Students. Atlantis Press, 102(Ictvt), 251-256. https://doi.org/10.2991/ictvt17.2017.43

Masykur, R., Nofrizal, \& Syazali, M. (2017). Pengembangan Media Pembelajaran Matematika dengan Macromedia Flash. Al-Jabar: Jurnal Pendidikan Matematika, $8(2)$, 177-186. https://doi.org/10.15797/concom.2 019..23.009

Mullis, I. V. S., Martin, M. O., Foy, P., \& Hooper, M. (2015). TIMSS 2015 International Results in Mathematics.

Munandar, A., \& Rizki, S. (2019). Pengembangan Bahan Ajar Matematika Berbasis Komputer Menggunakan Flipbook Maker Disertai Nilai Islam Pada Materi Peluang. AKSIOMA : Jurnal Program Studi Pendidikan Matematika, 8(1), 262-269.

Munawaroh, S., Degeng, I. N. S., \& Sitompul, N. C. (2021). Pengembangan Bahan Ajar Matematika Materi Bilangan Berbasis Higher Order Thingking Skills (HOTS). Edcomtech: Jurnal Kajian Teknologi Pendidikan, 6(1), 124-139.

Muruganantham, G. (2015). Developing Of E-Content Package By Using ADDIE Model. International Journal of Applied Research, 1(3), 52, p 52-54. Retrieved from http://www.allresearchjournal.co $\mathrm{m} /$ vol1issue3/PartB/pdf/67.1.pdf
Musfiqi, S., \& Jailani. (2014). Pengembangan Bahan Ajar Matematika yang Berorientasi pada Karakter dan Higher Order Thinking Skill (HOTS). Pythagoras: Jurnal Pendidikan Matematika, 9(1), 45-59. https://doi.org/10.21831/pg.v9i1.9 063

OECD. (2020). PISA 2018 Results (Volume VI) : Are Students Ready to Thrive in an Interconnected World?

Perwitasari, S., \& Akbar, S. (2018). Pengembangan Bahan Ajar Tematik Berbasis Kontekstual. Jurnal Pendidikan: Teori, Penelitian, Dan Pengembangan, 3, 278-285.

Rosyi, F., Hartono, \& Fatirul, A. N. (2020). Kelayakan Bahan Ajar Materi Perbandingan Trigonometri yang Berorientasi HOTS pada Siswa SMA. Edcomtech: Jurnal Kajian Teknologi Pendidikan, 5(1), 3850.

Sagala, R., Umam, R., Thahir, A., Saregar, A., \& Wardani, I. (2019). The effectiveness of stem-based on gender differences: The impact of physics concept understanding. European Journal of Educational Research, 8(3), 753-761. https://doi.org/10.12973/eujer.8.3.753

Sugiyono. (2015). Metode Penelitian Pendidikan: Kuantitatif, Kualitatif dan $R \& D$ (22nd ed.). Bandung: ALFABETA.

Triyono, M. B., Wardani, R., Hariyanto, D., \& Subhan, A. (2012). Pengembangan Interaktif e-Book dari Sisi Pedagogik, Teknologi Perangkat Lunak Serta Media yang Digunakan. In Universitas Negeri Yogyakarta. Retrieved 
DOI: https://doi.org/10.24127/ajpm.v10i2.3578

from

http://staffnew.uny.ac.id/upload/1 32315977/penelitian/Interaktif+eBook+UNY.pdf

Widodo, T., \& Kadarwati, S. (2013). Higher Order Thinking Berbasis Pemecahan Masalah Untuk Meningkatkan Hasil Belajar Berorientasi Pembentukan Karakter Siswa. Jurnal Cakrawala Pendidikan, 5(1), 161-171.

Yuherni, Maimunah, \& Yuanita, P. (2020). Bahan Ajar Matematika Berbasis Kontekstual Pada Materi Fungsi Untuk Meningkatkan Kemampuan Pemecahan Masalah Matematis. AKSIOMA: Jurnal Program Studi Pendidikan Matematika, 9(4), 1293-1306.

Yulianti, Buchori, A., \& Murtianto, Y. H. (2017). Pengembangan Media Presentasi Visual dengan Pendekatan Kontekstual dalam Pembelajaran Matematika di SMP. MUST: Journal of Mathematics Education, Science and Technology, 2(2), 231-242. https://doi.org/10.30651/must.v2i 2.859 